

\section{ENGINEERING CHANGE NOTICE}

16. Design Verilication

Required

Ores

No
17. Cost Impact

ENGINEERING

Additional $\mathrm{O}$

Savings $O \leqslant N / A$
Page 2 of 2

1. ECN (use no. from pg. 1)

654019

18. Schedule Impact (days)

CONSTRUCTION

Additional $\bigcirc s$

$\$ N / A$

Savings

0

related documents (other than the engineering
ter the affected document number in Block 20 .

ments identlified on Side 1) that will be affected by

SDD/DD

Functional Design Criteria

Operating Specification

Criticality Specification

Conceptual Design Report

Equipment Spec.

Const. Spec.

Procurement Spec.

Vendor Information

OM Manual

\section{FSAR/SAR}

Safoty Equipment List

Radiation Work Permit

Environmental Impact Statement

Environmental Report

Environmental Permit
Seismid/Stress Analysis

Stress/Design Report

Interface Control Drawing

Callbration Procedure

Installation Procedure

Maintenance Procedure

Engineering Procedure

Operating Instruction

Operating Procedure

Operational Safety Requirement

IEFD Drawing

Cell Arrangement Drawing

Essential Material Specification

Fac. Proc. Samp. Schedule

Inspectlon Plan

Inventory Adjustment Request
Tank Calibration Manual

Health Physics Procedure

Spares Multiple Unit Listing

Test Procedures/Specification

Component Index

ASME Coded Item

Human Factor Consideration

Computer Soltware

Electric Circuit Schedule

ICRS Procedure

Process Control Manual/Plan

Process Flow Chart

Purchase Requisition

Tickler File

None

20. Other Affected Documente: (NOTE: Documents listed below will not be revised by this ECN.) Signatures below indicate that the signing organization has been notified of other affected documents listed below.

$N / A$

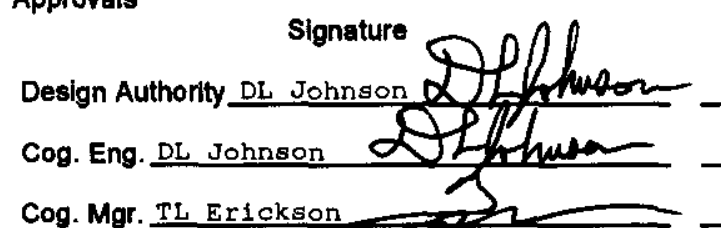

Date

\section{QA}

Safoty
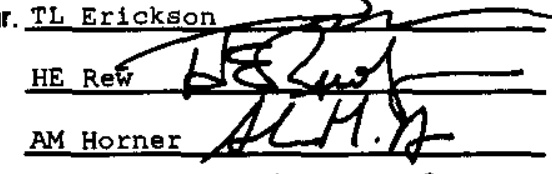

Environ. DE Rasmussen Damy F Parmuesen $8 / 27 / 82$

Other

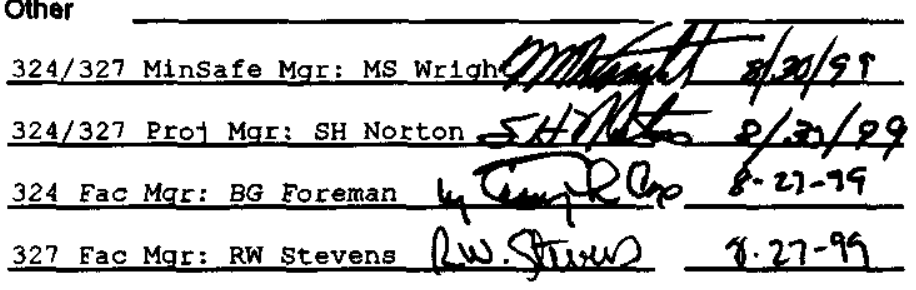

Signature

Date
Design Agent DL Johnson

PE

QA

Safety

Design

Environ.

Other

\section{DEPARTMENT OF ENERGY}

Signature or a Control Number that tracks the Approval Signature

ADDITIONAL 


\section{4/327 Facilities Environmental Effluent Specifications}

D. I. Johnson

BWHC

Richland, WA 99352

U.S. Department of Energy Contract DE-AC06-96RL13200

EDT/ECN: 654019

UC: 2000

Org Code: 19500

B\&R Code: EW7050000

Charge Code: $101021 / C A 40 \mu \mathrm{H}+N 990031$
Total Pages: 42 ,a

Key Words: Effluent, Specifications, Environmental, Monitoring, $324 / 327$ Facilities

Abstract:

These effluent specifications address requirements for the $324 / 327$ Facilities, which are undergoing stabilization activities. Effluent specifications are imposed to protect personnel, the environment and the public, by ensuring adequate implementation and compliance with federal and state regulatory requirements and Hanford programs.

TRADEMARK DISCLAIMER. Reference herein to any specific commercial product, process, or service by trade name, trademark, manufacturer, or otherwise, does not necessarily constitute or imply its endorsement, recommendation, or favoring by the United States Government or any agency thereof or its contractors or subcontractors.

Printed in the United States of America. To obtain $\infty$ pies of this document, contact: Document Control Services, P.O. Box 950, Mailstop H6-08, Richland WA 99352, Phone (509) 372-2420; Fax (509) 376-4989.
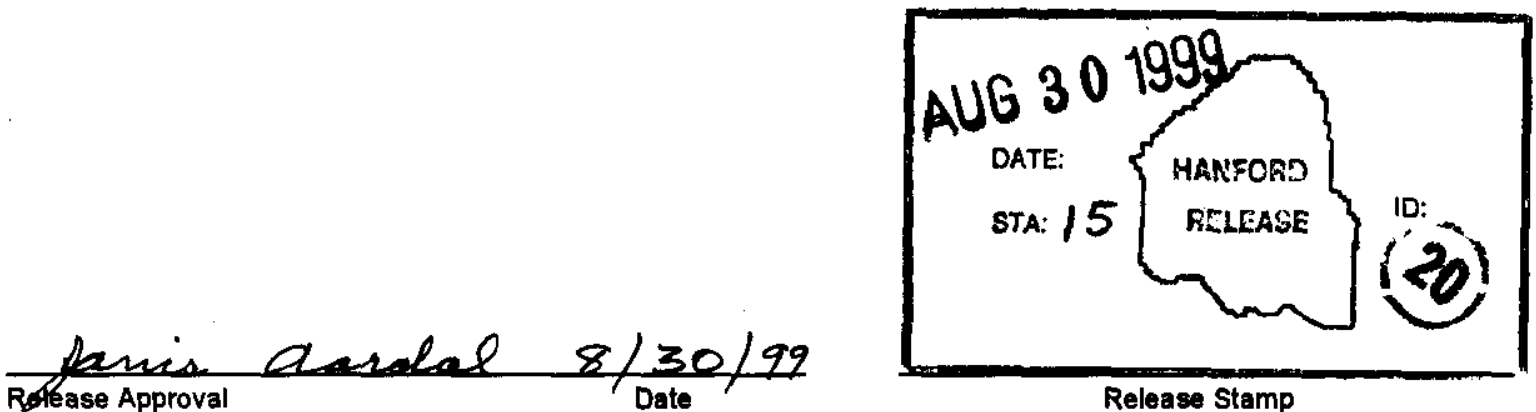


\section{RECORD OF REVISION}

Page 1

(2) Titie

324/327 Facilities Environmental Effluent Specifications

Change Control Record

(3) Revision

1 RS $\quad \begin{aligned} & \text { (7) } \\ & \text { Conp }\end{aligned}$

Complete document revision, per ECN-654019.
(4) Description of Change - Replace, Add, and Delete Pages

\begin{tabular}{ll|l}
1 & Complete document revision, per ECN-654019. \\
\hline &
\end{tabular}

Authorized for Release

\begin{tabular}{l|ll} 
(5) Cog. Engr. & (6) Cog. Mgr. Date \\
\hline
\end{tabular}

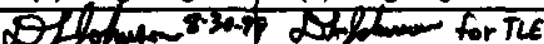

TL Erickson 8-36.99 


\title{
324/327 Facilities Environmental Effluent Specifications
}

\author{
Table of Contents
}

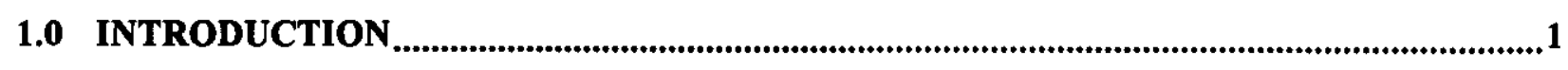

1.1 SCOPE

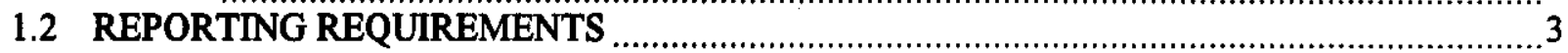

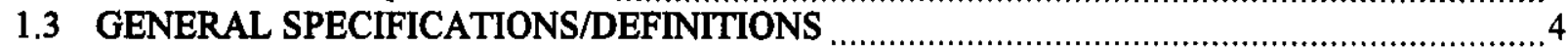

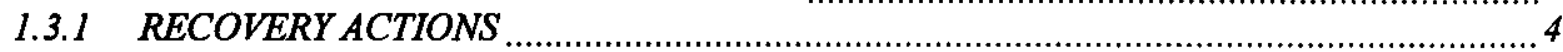

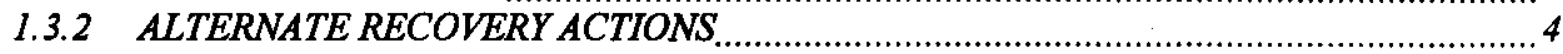

1.5 RECORD RETENTION REQUIREMENTS ........................................................... 8

2.0 AIRBORNE EFFLUENT CONTROL SPECIFICATIONS _................................................11

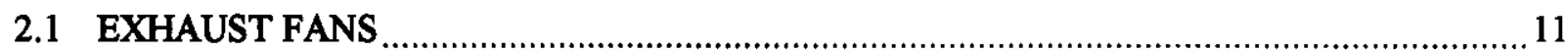

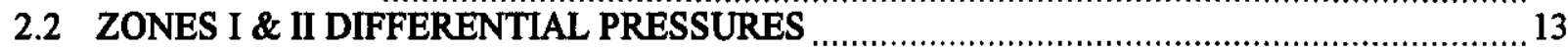

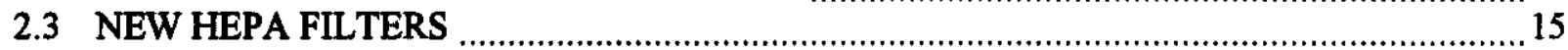

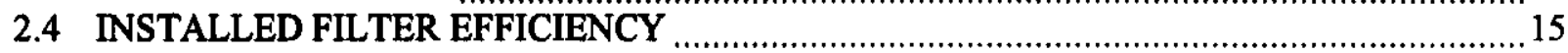

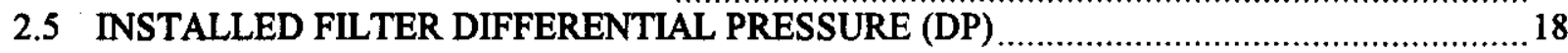

3.0 AIRBORNE EFFLUENT MONITORING SPECIFICATIONS ............................................20

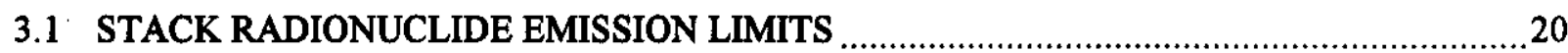

3.2 STACK EMISSION MEASUREMENT/MONITORING EQUIPMENT OPERABILITY .........23

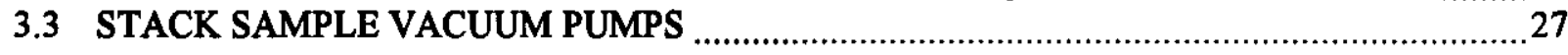

4.0 LIQUID EFFLUENT SPECIFICATIONS............................................................................29

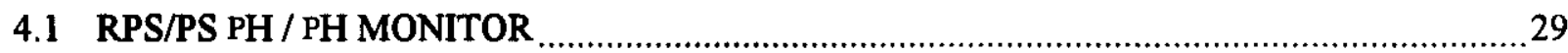

4.2 RPS/PS RADIONUCLIDE CONCENTRATIONS/ RPS RADIATION

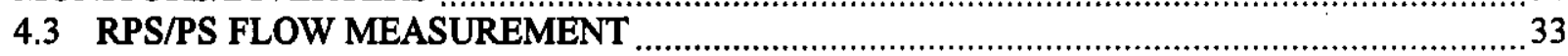

4.4 RPS/PS CHEMICAL CONCENTRATIONS ………………

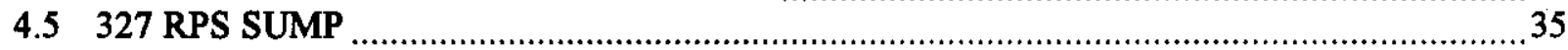

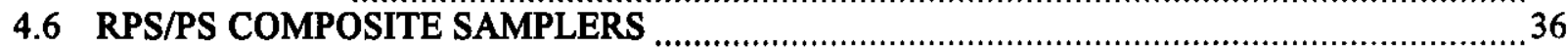

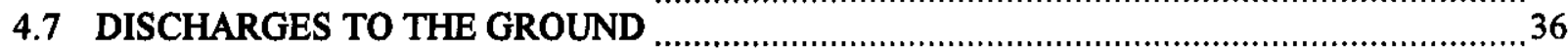

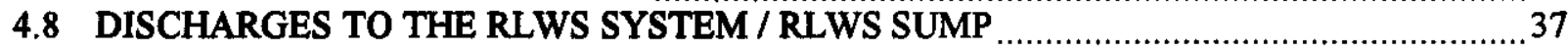

APPENDIX - SPECIFICATION TRACEABILITY MATRIX ....................................................38 


\section{$1.0 \quad$ INTRODUCTION}

These effluent technical specifications address requirements for the 324/327 facilities, which are undergoing stabilization activities. Effluent specifications are imposed to protect personnel, the environment and the public, by ensuring adequate implementation and compliance with federal and state regulatory requirements and Hanford programs.

Effluent specifications include instrumentation/equipment operability requirements, control settings, calibration frequency, surveillance frequency and process variable operating limits and measurement requirements. Recording of various parameters (e.g., pressure, flow, operating status) is required in some cases to provide an auditable record of compliance with the specifications. The required data collection frequency and format is provided in plant operating procedures. Retention of these records for ready retrievability provides compliance with state regulations. These records are specified in the Appendix.

This effluent specification document is to serve a function similar to an Operational Safety Requirement (OSR) document. Just as facility operating safety requirements are summarized in OSRs, facility environmental requirements are summarized in these effluent specifications. (Some effluent specifications relate to certain OSRs, but they are generally derived from different sources than OSRs, and have a different range of scope. OSRs are derived from accident analyses and are intended to avoid large doses to the public under upset conditions. Effluent specifications are derived from environmental regulations/requirements that are concerned with upset conditions as well, but with emphasis on potentials for chronic low doses to the public under normal operating conditions.) Some effluent specifications reflect elements of some OSRs (HNF-SD-SPJ-OSR001, Rev. 1, and HNF-SD-SPJ-OSR-002, Rev. 2). Related OSRs are referenced in the Basis for Limit section of the effluent specification. These effluent specifications have been reviewed to ensure consistency with related OSRs. 


\subsection{SCOPE}

The airborne effluent specifications provided for the 324/327 facilities are based on requirements contained in:

- $\quad 40$ CFR 61 Subpart H, "National Emission Standards for Emissions of Radionuclides Other Than Radon From Department of Energy Facilities"

- WAC 246-247, "Radiation Protection-Air Emissions"

- $\quad$ Facility-specific Notice of Construction (NOC) regulatory permits, including: - $\quad$ NOC for Cleanout of the WTEL B-Cell, 324 Building, AIR 95-903

- Hanford Site Air Operating Permit HNF-AOP-97-1, including the Hanford Radioactive Air Emission License FF-01 with the State of Washington Department of Health

- $\quad$ DOE Regulatory Guide DOE/EH-0173T

- $\quad$ FDH HNF-PRO-450 “Air Quality - Radioactive Emissions"; HNF-PRO-2364, "Radioactive Airborne Effluent Sampling".

- $\quad$ Facility Effluent Monitoring Plans (FEMP) for the 324 and 327 facilities

Requirements and approval conditions provided in Notice of Construction (NOC) regulatory permits are considered regulatory requirements. These requirements may be implemented through facility procedures as appropriate (e.g., stack air sampling). Deviation from NOC or other regulatory requirements may not be made without appropriate concurrence from the regulator.

The liquid effluent specifications are based on the requirements contained in the Waste Acceptance Criteria for the 300 Area Process Sewer \& TEDF, and the Liquid Waste Certification Program, both contained in WMH-320. The approved 300 Area Liquid Effluent Facilities Administration, section 3.4, Liquid Waste Certification Program requirement states that waste generating facilities "Ensures all personnel who control discharge of materials to either the PS or RPS systems are aware of the system limitations." These are driven by TEDF process control requirements and the EPA NPDES Permit WA-002591-7, which regulates TEDF discharge to the Columbia River.

Implementation of the effluent specifications for the 324/327 facilities will be accomplished through appropriate updates to operating procedures, instrument and equipment calibration data, preventive maintenance procedures, and personnel training. Operability testing and calibration schedules for equipment and instruments required to support the specific requirements are established and executed in accordance with HNF-IP-1264, section 4.2, "Preventive Maintenance." 


\subsection{REPORTING REQUIREMENTS}

In general, specification noncompliance including entry into a recovery action shall be reported by the responsible supervisor within eight hours of discovery to the 324/327 Facility Manager, to the Environmental Compliance Officer (ECO), and to the effluent cognizant engineer. However, noncompliance with certain effluent-related specifications requires notification of site Effluent Monitoring, the FDH point of contact, DOE, and regulatory agencies within 24 hours, as determined by the ECO. The FDH point-of-contact notifies WDOH, as appropriate.

Specification violations include:

1) exceeding certain specification limits

2) failure to comply with an operating specification and the associated Recovery Action, and

3) failure to perform a surveillance requirement (e.g. calibration or inspection) within the specified interval plus any allowable extension (see Section 1.3.1 for allowable extensions).

Specification violations that result in regulatory notifications include the following:

- Below minimum fan operation,

- Below minimum HEPA efficiency,

- Emissions above normal resulting from operational changes,

- Exceeding allowable monitoring/measurement equipment downtime,

- Positive pressurization of radioactive contaminant ventilation zones

- Exceeding annual test schedules for HEPA filter efficiency (Table 2.4), stack effluent measurement/monitoring instruments calibration (Table 3.2), and stack flow measurement

Specification violations may be indicative of degradation in the safety, environmental, or health protection performance of the facility. Formal occurrence reporting may be required when a violation occurs. Specification violations shall be reported/documented as directed by HNF-PRO060, Reporting Occurrences and Processing Operations Information. 


\subsection{GENERAL SPECIFICATIONS/DEFINITIONS}

\subsubsection{RECOVERY ACTIONS}

In general, the Recovery Action lists those corrective actions that are necessary in order to correct or prevent non-compliant conditions. The Basis for Limit will clarify whether or not these are required or recommended actions. The time limits for initiation of repair or replacement in the recovery actions are generally provided as guidelines to ensure timely response to correct or prevent non-compliant conditions. When the specified time limits are based on specific regulating requirements, it will be noted in the Basis for Limit.

Unless specified otherwise in this document, the minimum calibration frequency for airborne effluent instruments shall be annual. The calibration frequency for liquid effluent instruments shall be as determined by the cognizant engineer, based on reliability of the instrument. Applicable instruments shall be in current calibration and operable prior to use. If an instrument is not calibrated or a preventive maintenance (PM) or a functional test is not performed within the specified frequency:

- For airborne effluent instruments/equipment, perform the calibration, PM or test within the month of the specified due date. If an annual calibration or test cannot be performed within the month due, the FDH point of contact and WDOH must be notified, and calibrations must be completed as soon as possible.

- For liquid effluent instruments/equipment, perform the calibration, PM or test within an extension of $25 \%$ of the specified frequency.

Basis for Limit: The above recovery action plans provide for flexibility that may be needed due to plant conditions or personnel shortages. The overview provided by the independent organizations ensures that personnel, environment and public safety are adequately considered.

The above $25 \%$ surveillance (see definition) extension limitation is based on Section II.2.1.i of DOE Order 5480.22 Attachment 1, "Guidelines for Technical Specification Requirements," (TSRs). The extension provides early warning and focuses attention on the problem in time to avoid a specification violation. The extension allowance is intended to provide operational flexibility both for scheduling and for performing surveillance. It should not be relied upon as a routine extension of the specified interval.

\subsubsection{ALTERNATE RECOVERY ACTIONS}

If a specified recovery action for a non-compliant condition can not be completed within the specified time or, due to unusual circumstances/conditions, another action is more appropriate than that listed in this document, then:

- Prepare a plan and obtain written concurrence within 96 hours of the specified time or frequency from the 324/327 Facility Manager, ECO, WMH Effluent Monitoring, and the FDH point of contact (as appropriate). 


\subsection{DEFINITIONS}

$\underline{\text { Term }}$

AOP

Action

Alternate

Annual

Calibrate

Completion time

CAM

Control

Daily

Data collection

Deactivate

Deactivation

Detection/Control

ECO
Definition

Hanford Site Air Operating Permit, HNF-AOP-97-1 (draft)

Prescribes remedial measures required under designated conditions for a specification.

A backup for the primary instrument that is used to provide the required data or indication until the primary instrument is returned to service.

An interval from a given month to the end of that same month the following year.

To systematically standardize a quantitative measuring instrument.

The amount of time allowed to complete a required Action referenced to the time of discovery.

Continuous Air Monitor.

Devices or methods required to maintain safe conditions.

Normal business day, excluding weekends and holidays.

Recording of various parameters (pressure, temperature, flow, volume, specific gravity, etc.) providing an auditable record of compliance with the specifications. The frequency and format is provided in plant operating procedures.

To prevent operation of a system, component, or device by precluding the application of the energy source required for operation and/or by providing engineered modifications to prevent the system, component, or device from performing its function(s).

Facility activities related to removing, reducing, and stabilizing the remaining radioactive and chemical materials from the facility, followed by eventual shutdown of the utilities and effluents.

States how the variable associated with the limit is measured and/or controlled. Real time measurement is desired but may not always be possible.

Environmental Compliance Officer or delegate. Delegate may be the effluent cognizant engineer for purposes of these specifications. 
EPA

ESP

Facility

FEMP

FDH

Functional Check

Immediately

Initiate repair

In-service

Interpretive Authority

Isolate

LEF

Manager

Monitoring

Noncompliance
The United States Environmental Protection Agency.

Electrostatic Precipitators (used as prefilters in 324 B-Cell).

The entire process and necessary support equipment as defined by the Safety Analysis Report (SAR) and FEMP.

Facility Effluent Monitoring Plan.

Fluor Daniel Hanford, Inc.

The qualitative assessment of instrument or equipment behavior during operation by observation. This determination shall include, where possible, comparison of the output indication and/or status with other indications and/or status derived from independent instruments or equipment measuring the same parameter. A functional check is used to determine if the instrument or equipment is operable.

Performing an Action without delay, but in a safe, controlled manner.

The required maintenance work order has been initiated and planning is in progress. Response time limits are guidelines unless otherwise specified.

A system, component, device, instrument, or equipment piece shall be inservice when it is operable and being used.

The interpretive authority for the Effluents Technical specifications shall be the $324 / 327 \mathrm{ECO} /$ delegate.

Provide a positive barrier to preclude any unwanted solution flow or material transfer from one vessel or system to another. Isolation is typically achieved by installing blanks, removing piping or jumpers, or deactivating transfer devices such as pumps.

Liquid Effluent Facilities. Includes TEDF, the 307 basins, and the 340 Facility (the 340 Facility has been shut down).

Term, as used in this document, includes delegated individual.

The measurement of a process variable; includes routine surveillance and testing, measurement of radioactive material by means of a radiation detector and/or withdrawal of representative samples for laboratory analysis.

A condition outside the boundaries of the specification caused by commission or omission. 
Off-Normal

Occurrence

Operable

Operating

Recovery Action

Specification Violation

Action. Also, failure to perform a surveillance requirement within the specified interval plus any allowable extension (see Section 1.3.1).

Surveillance

Activity related to test, calibration, or inspection to ensure the quality and operability of safety-related structures, systems, components, and associated support systems are maintained.

Surveillance Frequency See the definitions given below from Section II.2.1.d of DOE Order 5480.22 Attachment 1, "Guidelines for Technical Specification Requirements," (TSRs). (Also applies to Data Collection Frequency.)

\begin{tabular}{|c|c|c|}
\hline & Minimum Frequency \\
\hline \multicolumn{2}{|c|}{ S- Shift } & At least once per 12 hours. \\
\hline D - & Daily & Once per 24 hours. \\
\hline W - & Weekly & Once per 7 days. \\
\hline M - & Monthly & Once per 31 days. \\
\hline Q - & Quarterly & Once per 92 days. \\
\hline SA - & Semi-annually & Once per 184 days. \\
\hline C - & Campaign & Prior to each startup. \\
\hline A - & Annually & Once per 365 days. \\
\hline
\end{tabular}

Technical Basis Describes the reason(s) for the stated limit and applicable safety considerations.

TEDF 300 Area Treated Effluent Disposal Facility.

WDOH Washington State Department of Health. 


\subsection{RECORD RETENTION REQUIREMENTS}

Surveillance and maintenance records on all systems identified in this procedure must be retained for a minimum of five years at the facility ( 327 records may be retained together at 324 facility) to ensure that records are "readily retrievable", as required by WAC 246-247. DOE letter 97-EAP-388 documents the agreement between DOE and WDOH that "readily retrievable" is to be interpreted that records "shall be provided (to WDOH) by close of business the following business day of their request." Since these records must be processed through FDH prior to being provided to $\mathrm{WDOH}$, it is necessary to be capable of retrieving records from the facility in less than 24 hours. This generally makes storage of records at the facility necessary. Records are not required to be original documents; readable copies are adequate.

Records required to be maintained at the facility are included in the outline below, as applicable (list is excerpted from the Hanford Radioactive Air Emission License FF-01 with the State of Washington Department of Health, which is included in the Hanford Site Air Operating Permit HNF-AOP-97-1). Specific records that must be retained are listed in the Appendix.

\section{Section 1 - Records Required by 40 CFR 61.14 (f) and WAC 246-247-080.}

[Note: For NESHAP Designated Stacks Only]

\section{Calibration Records}

- Records and procedures for stack sampling system instrumentation, functional checks/periodic calibrations (i.e. vacuum gauges, rotameters, and gas meters).

Monitoring Data

- $\quad$ Stack flow data, and sampling data including flow rate calculations (e.g. vent and balance).

- $\quad$ The Radioactive Air Emissions Report for the Hanford Site (NESHAP annual report)

- Documentation verifying compliance with Quality Assurance requirements of 40 CFR 61, Subpart H, Appendix B, Method 114 (e.g., The Quality Assurance Program for Radionuclide Airborne Emissions Monitoring, the Effluent Monitoring Quality Assurance Project Plan for Radioactive Airborne Emissions Data, and the Quality Assurance Plan for Facility Effluent Monitoring, Quality Assurance Plan No. FO-011)

- Records documenting periods of malfunction or in operation (i.e., monitoring system down time)

\section{Section 2 - Records Required by 40 CFR 61.95 and WAC 246-247-080.}

[Note: As Applicable, For All Sources of Radioactive Air Emissions]

Monitoring Data (for powered, ventilated point sources)

- $\quad$ Stack flow data, and sampling data including flow rate calculations (e.g. vent and balance).

- The Radioactive Air Emissions Report for the Hanford Site (NESHAP annual report)

- NESHAP assessments

Passively Ventilated Point Sources (contained in Table 2.2)

- See compliance schedule 


\section{Nonpoint Source and Fugitive Emissions}

- The Radioactive Air Emissions Report for the Hanford Site (NESHAP annual report) The annual Hanford Site Environmental Report

\section{Notices of Construction}

- Notice of Construction Applications

- Approval orders (letters) from EPA/WDOH including any additional approval conditions

\section{Section 3 - State-only Records Required by WAC 246-247-080(8)}

\section{BARCT and ALARACT Demonstrations}

- $\quad$ Records of Best Available Radionuclide Control Technology (BARCT) and/or As Low As Reasonably Achievable Control Technology (ALARACT) demonstrations

\section{Drawings and Blueprints (for major stacks)}

- Configuration drawings and/or process flow diagrams of radioactive air emission unit effluent control and monitoring systems

\section{Line Loss Studies (if performed)}

- $\quad$ Estimated and documented line losses and sample collection efficiency studies completed at the direction of the WDOH

\section{Calibration and Maintenance Records and Procedures}

- Maintenance records, maintenance procedures, and all original strip chart records (major stacks) or equivalent for all stack sampling system instrumentation (e.g., continuous air monitors, probes, pumps, rotameters, flow regulators, pressure gauges, totalizers, gas meters, and flow switches) as appropriate for methods identified in Tables 2.0 and 2.1

- Functional checks/periodic calibration records and procedures for all nondesignated stack instrumentation (i.e., vacuum gauges, rotameters, and gas meters).

- Maintenance records and maintenance procedures for required abatement control technology equipment identified in Tables 1.0 and 1.1

Efficiency Tests of high efficiency particulate air (HEPA) filters

- $\quad$ Test procedures and results of the HEPA filter/aerosol tests.

\section{Training}

- Training records of personnel and supervisors specific to the operation and maintenance of radioactive air emission units.

\section{Reports}

- Reports of closure

- 10-day notification follow-up reports

\section{Operation Log}

- $\quad$ Gategorically approved units 
- Specific regulatory order approval condition

\section{Quality Assurance Program}

- Documentation verifying compliance with Quality Assurance requirements of WAC 246247-075(6) (e.g., The Quality Assurance Program for Radionuclide Airborne Emissions Monitoring, the Effluent Monitoring Quality Assurance Project Plan for Radioactive Airborne Emissions Data, and the Quality Assurance Plan for Facility Effluent Monitoring, Quality Assurance Plan No. FO-011)

For portable units identified and given categorical approval to operate under this license, a log shall be maintained in accordance with WAC 246-247-080(7) and shall contain relevant operations parameters including, but not limited to the date, location, duration of the release, measured or calculated radionuclide concentrations, the type of emissions (liquid, gaseous, solid), and the type of emission control and monitoring equipment.

[WAC 173-401-615(2)] 


\subsection{AIRBORNE EFFLUENT CONTROL SPECIFICATIONS}

\section{$2.1 \quad$ EXHAUST FANS}

Variable

Zones I \& II Exhaust Fan Operability

Exhaust Fan Downtime, Below Normal

Exhaust Fan Downtime, Below Minimum

\section{Specification}

See table below

Exhaust fan downtime for scheduled maintenance to less than normal operation, but meeting the minimum operation requirements shall be limited to 24 hours unless prior approval is obtained from the ECO and/or effluent cognizant engineer.

Exhaust fan downtime for scheduled maintenance to less than minimum operation requires prior approval from the ECO and/or effluent cognizant engineer.

\begin{tabular}{|l|l|l|}
\hline \multicolumn{1}{|c|}{ SYSTEM } & \multicolumn{1}{|c|}{ NORMAL OPERATION } & \multicolumn{1}{c|}{ MINIMUM OPERATION } \\
\hline 324 Zone I Exhaust & $\begin{array}{l}2 \text { of } 3 \text { fans operating (typically } \\
\text { EP-973 and EP-975 operating, } \\
\text { EP-974 in standby) }\end{array}$ & 1 fan operating \\
\hline 324 Zone II Exhaust & EP-971 and EP-972 operating & 1 fan operating \\
\hline 327 Zone I (Hot Cell) Exhaust & HEF\#1 or HEF\#2 operating & 1 fan operating \\
\hline 327 Zone II (Cold) Exhaust & CEF\#1 and CEF\#2 operating & 1 fan operating \\
\hline $\begin{array}{l}327 \text { Decontamination Cell } \\
\text { Exhaust }\end{array}$ & 1 fan operating & 1 fan operating \\
\hline
\end{tabular}

Detection/Control: Exhaust fan operation is verified as indicated on the Power Operator data sheets. Preventive maintenance is performed periodically to support operability.

Recovery Action: If active ventilation can not be immediately restored, take necessary steps as determined by 324/327 Facility Manager and cognizant engineer to minimize effects and curtail operations in the affected area as appropriate. Notify the ECO and/or effluent cognizant engineer. If exhaust fans become inoperable such that the minimum operability requirements are not met:

- Verify that the supply fans are off

AND

- Verify that Zones I \& II DP is maintained below the atmospheric reference pressure per specification 2.2

\section{AND}

- Notify 324/327 Facility Manager, ECO and effluent cognizant engineer (See 1.2) 
- Provide additional notifications (i.e. to FDH, DOE, and WDOH) within 24 hours of discovery and submit documentation of the event as required (see 1.2).

\begin{abstract}
AND
- Initiate repair within 96 hours.

Basis for Limit: The uncontrolled spread of airborne contamination within and to outside of the process areas is prevented by the building ventilation system. The probability of contamination release to the environs is minimized by maintaining progressively decreasing pressures from uncontaminated or cold zones to the highly contaminated process cells or gloveboxes, and by pulling the exhaust air from these areas through high-efficiency filters. Also, the level of contamination within the various zones of the controlled area and the probability of an uncontrolled release within these zones are held acceptably low by maintaining the specified minimum exhaust capability and differential pressure.
\end{abstract}

Partial loss of exhaust capability does not present a direct hazard. If exhaust fans minimum operability requirements are not met, Zones I \& II activity is limited to that necessary to maintain/restore safe conditions. The supply fans are off under these conditions to prevent pressurization of Zones I \& II.

The ECO/delegate must give prior approval for scheduled downtime of greater than 24 hours. This ensures an opportunity for the ECO/delegate to provide alternate stack sample flow rate settings to facilitate representative isokinetic sampling. The basis is further described in the FEMP documents. Isokinetic sampling requirements are driven by 40 CFR 61, Subpart H.

The exhaust fan minimum operability requirements are based on AOP requirements. Exhaust fan operation prevents fugitive emissions from uncontrolled pathways by drawing building air through controlled and monitored effluent systems. Operation below these minimum requirements will prompt regulatory notifications (per AOP) and require alternate stack sample flow rate settings to facilitate representative isokinetic sampling (per FEMP and 40 CFR 61, Subpart H). 


\subsection{ZONES I \& II DIFFERENTIAL PRESSURES}

$\underline{\text { Variable }}$

Zones I \& II DP

DP Instruments
Specification

Zones I \& II plenum pressure below* atmospheric reference pressure

Operable and calibrated annually

${ }^{*}$ Recommended $\geq 0.1$ in. w.g. below atmospheric reference pressure

Detection/Control: The differential pressure (DP) between Zones I \& II and atmospheric reference pressure is measured by the instrumentation listed below. Calibration of these instruments is conducted annually.

\section{ZONES I \& II PRESSURE INSTRUMENTS}

\begin{tabular}{|l|l|l||}
\hline FACILITY & \multicolumn{1}{|c|}{ INSTRUMENT } & \multicolumn{1}{c|}{ ALARM } \\
\hline 324 & $\begin{array}{l}\text { Zone I Exhaust Plenum Pressure } \\
\text { Zone II Exhaust Plenum Pressure }\end{array}$ & $\begin{array}{l}\text { High Exhaust Duct Pressure Zone I } \\
\text { High Exhaust Duct Pressure Zone II }\end{array}$ \\
\hline 327 & $\begin{array}{l}\text { Hot Exhaust Plenum Static Pressure } \\
\text { Cold Exhaust Plenum Static Pressure }\end{array}$ & $\begin{array}{l}\text { HEF Low Static Pressure } \\
\text { CEF Low Static Pressure }\end{array}$ \\
\hline
\end{tabular}

Recovery Action: If the above DP limits cannot be met:

- Immediately cease all affected activities

AND

- Evacuate and/or limit Zones I \& II entry to only those personnel necessary to maintain/restore safe conditions

AND

- Restore Zones I \& II pressure to below atmospheric reference pressure.

AND

- Notify 324/327 Facility Manager , ECO and effluent cognizant engineer (See 1.2)

AND

- Provide additional notifications (i.e. to FDH, DOE, and WDOH) within 24 hours of discovery and submit documentation of the event as required (see 1.2).

If the primary instrument fails:

- Initiate repair/replacement of the primary DP instrument within $96 \mathrm{~h}$. 
Basis for Limit: Complete loss of negative pressure in the Cell results in a high risk of loss of containment and contamination control in those areas. Loss of ability to maintain the specified minimum Zones I \& II differential pressure could potentially result in release of radioactivity to areas occupied by personnel and result in unmonitored fugitive emissions from the facility.

Radioactive emissions are required to be monitored according to WAC 246-247 and 40 CFR 61, Subpart H. Loss of Zones I \& II negative pressure would prompt a WDOH notification. 


\subsection{NEW HEPA FILTERS}

$\underline{\text { Variable }}$

HEPA Filter Particulate Removal Efficiency
Specification

$\geq 99.97 \%$

Detection/Control: High-efficiency particulate air (HEPA) filters for use in airborne effluent streams shall be tested for particulate removal efficiency prior to installation or placing the filter in-service. Testing shall be performed per the requirements of American National Standards Institute (ANSI) Standard N510. (Applies only to final exhaust filters (i.e., last filter bank prior to release to environment) of operating exhaust systems, as documented in the AOP, OSR and FEMP documents. Refer to Table 2.4 for the list of applicable filters. Although not required by this specification, testing is recommended for upstream exhaust filters upon replacement.)

Basis for Limit: The use and testing of new particulate air filters are intended to ensure radionuclide releases are maintained within acceptable concentration limits. Testing is performed on critical airborne effluent control systems. Testing is performed per the requirements of American National Standards Institute (ANSI) Standard N510. ANSI N510 is referenced in WAC 246-247 as a required technology standard. Per ANSI N510, "The filter shall exhibit a minimum efficiency of $99.97 \%$ when tested with an aerosol of essentially monodispersed 0.3 micron particles."

\subsection{INSTALLED FILTER EFFICIENCY}

$\underline{\text { Variable }}$

HEPA Filters* Particulate Removal Efficiency

HEPA Test Frequency
Specification

$\geq 99.95 \%$

Annual

Detection/Control: High-efficiency particulate air (HEPA) filters* installed in airborne effluent streams listed in Table 2.4 shall be tested in place for particulate removal efficiency prior to use and at least annually thereafter until removed from service. For these filters, exceeding the annual test frequency is a specification violation. See 1.2 and 1.3.1.

*Applies only to final exhaust filters (last filter bank prior to release to environment) of operating exhaust systems, as documented in the AOP, OSR and FEMP documents. (Refer to Table 2.4 for the list of applicable filters)

Recovery Action: If the above requirements cannot be met, take the appropriate action listed below:

- Notify 324/327 Facility Manager, ECO and effluent cognizant engineer (see 1.2)

AND

- Provide additional notifications (i.e. to FDH, DOE, and WDOH) within 24 hours of discovery 
and submit documentation of the event as required (see 1.2).

AND

- Where available, place parallel filter systems in service and take the failed filters out of service within $72 \mathrm{~h}$

OR

- Where no parallel filter system is available, shut down or limit operation of the offending exhaust system within 72 hours until the filters can be replaced or resealed

OR

- Restrict facility operations that have the potential to cause emissions.

If a HEPA filter listed in Table 2.4 is not tested by the annual due date (i.e. by the end of the month in which it comes due), then:

- Notify the 324/327 Facility Manager, ECO and effluent cognizant engineer (See Section 1.2)

AND

- Provide additional notifications (i.e. to FDH, DOE, and WDOH) within 24 hours of discovery, and submit documentation of the event as required (see 1.2)

AND

- Complete HEPA filter test as soon as possible.

Basis for Limit: The use and testing of high efficiency particulate air (HEPA) filters are intended to ensure radionuclide releases are maintained below acceptable concentration limits. Final HEPA exhaust filters are required to meet this specification. A review of the accident analyses in the SAR confirms that the maximum decontamination factor assumed for radioactive particulates was the equivalent of one stage of HEPA filtration. The high efficiency filter banks upstream of the final HEPA filters ensures exceeding the $99.95 \%$ efficiency assumed in the 324/327 SAR accident analyses and provides additional assurance of meeting discharge requirements. Credit for this additional decontamination has not been claimed from a regulatory standpoint and there are no conditions that require routine testing of these filters; however, it is recommended that they should be leak checked upon installation to ensure protection of the final filters.

The Nuclear Air Cleaning Handbook, ERDA 76-21, section 8.2 states that by definition a HEPA system must exhibit an installed decontamination factor of 2000; that is, an efficiency of 99.95 percent for aerosols having a median diameter less than 1 micrometer. ERDA 76-21 is referenced in WAC 246-247 as a required technology standard. The annual testing and efficiency requirement is consistent with facility OSR documents (324 OSR 2.1, 327 OSR 2.2). The recovery action timeframe is consistent with the more restrictive of facility OSR documents. 


\begin{tabular}{|c|c|c|}
\hline \multicolumn{3}{|c|}{ TABLE 2.4 REQUIRED HEPA FILTERS } \\
\hline $\begin{array}{l}\text { EMISSION } \\
\text { POINT }\end{array}$ & $\begin{array}{l}\text { VENTLATION } \\
\text { ZONE }\end{array}$ & FILTER LOCATION* \\
\hline \multirow[t]{6}{*}{ EP-324-01-S } & Zone I & final stage HEPA filters, Room 9 \\
\hline & Zone I & final stage HEPA filters, Room 10 \\
\hline & Zone I & POG, V/V final stage HEPA filters, Room 11 \\
\hline & Zone I & B-Cell, Electrostatic Precipitators (ESPs) \\
\hline & Zone II & final stage HEPA filters, Room 6 \\
\hline & Zone II & final stage HEPA filters, Room 7 \\
\hline \multirow[t]{16}{*}{ EP-327-01-S } & Zone I** & Cells A through I final stage HEPA filters \\
\hline & Zone I & Dry Cell final stage HEPA filters \\
\hline & Zone I & Storage Cell (Lower SERF Cell) final stage HEPA filters \\
\hline & Zone I & Rm15 (Low Level Lab) Hood HEPA \\
\hline & Zone II** & Canyon Exhaust HEPA filters 1-15 \\
\hline & Zone II & Serf Cell final stage HEPA \\
\hline & Zone II & Room 19 (E of SERF Cell) HEPA \\
\hline & Zone II & Room 19 (W of SERF Cell) HEPA \\
\hline & Zone II & Manipulator Repair, S Room 18 HEPA \\
\hline & Zone II & Manipulator Repair, N Room 18 final stage HEPA \\
\hline & Zone II & Room 17, PRTR Loadout HEPA \\
\hline & Zone II & Basement 1-6 HEPA \\
\hline & Zone II & Machine Shop Canopy HEPA \\
\hline & Zone II & Vacuum Air Sample HEPA, VAS-HEPA-B001 \\
\hline & Zone II & Manipulator Decontamination Room 20 HEPA \\
\hline & Zone II & Manipulator Decontamination Room 20 Hood HEPA \\
\hline EP-327-02-V & \multicolumn{2}{|c|}{ Decontamination Cell \& Waste Compactor final HEPA } \\
\hline
\end{tabular}

* Reference drawings H-3-49514, H-3-70224, and H-3-70261

** At 327, Zone I also termed Hot Exhaust and System C, Zone II also termed Cold Exhaust and System B. 


\subsection{INSTALLED FILTER DIFFERENTIAL PRESSURE (DP)}

Variable

HEPA Filter Stage Normal Operating DP*

HEPA Filter Stage Maximum Operating DP*

DP Instruments*

324 B-Cell ESPs
Specification

$\geq 0$ in. w.g. and $<5.0$ in. w.g.

8.0 in. w.g.

Operable and calibrated annually

Monitor ESP amperage and record daily (during B-Cell clean-out operations)

*Applies only to final exhaust filters of operating exhaust systems prior to release to environment.

Detection/Control: See Table 2.4 for a complete listing of applicable filters. Calibration of DP instruments is conducted annually. The filters with DP instruments are verified daily. A calibrated portable device may be used as an Alternate for any DPI instrument.

Recovery Action: Any instrument deficiencies identified during the investigation or calibration shall be corrected. Malfunctioning instruments for filtration systems shall be brought to the attention of the 324/327 Facility Manager, ECO and cognizant engineer upon detection and repair/replacement shall be initiated within 96 hours or the affected filter banks must be taken out of service.

If the $<5.0$ in. w.g. DP specification listed above cannot be met, follow the appropriate response below:

Where parallel backup HEPA filter systems are available:

- Put the parallel system in service

Where no parallel HEPA filter system is available:

- Notify 324/327 Facility Manager, ECO and effluent cognizant engineer (see 1.2)

\section{AND}

- Initiate replacement of the HEPA filter within 96 hours.

\section{AND}

- If the HEPA filter DP increases to 8.0-in. w.g. before it can be replaced, monitor and reduce flow through the affected exhaust system (See section 2.1 for exhaust fan requirements).

Basis for Limit: The 5 in. w.g. DP limit for HEPA filters is required by FDH through HNF-PRO450, and is therefore the basis for initiating HEPA filter replacement. The 8.0-in. w.g. maximum 
HEPA filter DP is intended to ensure the HEPA filters are not breached. These values are very conservative as each HEPA filter stage is designed to withstand a DP of 10.0-in. w.g, and used HEPA filters should be able to withstand a DP of 8.0 -in. w.g (Nuclear Air Cleaning Handbook, ERDA 76-21). The daily record of ESP amperage is a WDOH condition of the B-Cell Clean-out NOC permit AIR 95-903. 


\subsection{AIRBORNE EFFLUENT MONITORING SPECIFICATIONS}

\subsection{STACK RADIONUCLIDE EMISSION LIMITS}

\section{Variable}

Emergency Radionuclide* Emission Limits

Annual Radionuclide* Emission Limits

Measurement

Reporting

\section{Specification}

The emission quantity that would cause an offsite effective dose equivalent of $2 \mathrm{mrem} / \mathrm{event}$. See Table 3.1 below.

The combined discharge of radionuclide emissions in air from all Hanford Site facilities shall not exceed those amounts that would cause any member of the public to receive in any year an effective dose equivalent of $10 \mathrm{mrem} /$ year.

Determine quantity and volume of radioactive materials emitted from each stack with potential radionuclide emissions.

Report quantity/volume annually to the DOE and regulatory agencies.

\begin{tabular}{|c|r|c||}
\hline \multicolumn{3}{|c||}{ TABLE 3.1 } \\
\multicolumn{3}{|c|}{ STACK RADIONUCLIDE* EMISSIONS } \\
EMERGENCY LIMITS \\
\hline Stack & EP-324-01-S & EP-327-01-S \\
\hline Total Alpha & $400 \mathrm{cps}$ & $40 \mathrm{cpm}$ \\
\hline Total Beta & $7,000 \mathrm{cps}$ & $4,000 \mathrm{cpm}$ \\
\hline
\end{tabular}

${ }^{*}{ }^{238} \mathrm{Pu}$ is the most limiting alpha and ${ }^{90} \mathrm{Sr}$ and ${ }^{137} \mathrm{Cs}$ are the most limiting beta.

Detection/Control: The Emergency Limit for the 324/327 facilities is the emission quantity that would cause an offsite effective dose equivalent of $2 \mathrm{mrem} / \mathrm{event}$. Early indication of a plant emergency is given by the appropriate monitor listed in Table 3.2 and confirmed or evaluated by laboratory analyses of record samples or grab samples. The authenticity of an emergency level is to be verified immediately upon onset of stack CAM alarms. Recovery actions are to be performed immediately once it is verified that the emissions are real. Confirmation of a problem is obtained by analysis of samples taken from the record sampler or an alternate location on an accelerated schedule.

The annual radionuclide emission limit is defined by 40 CFR 61 , Subpart $H$, as an amount that 
would cause any member of the public to receive in any year an effective dose equivalent of 10 mrem/year. Compliance with the annual limit is demonstrated by laboratory analyses of record samples from all stacks with potential emissions. In the event of Hanford facility exceedence of annual emission limits, or if it appears likely that any DOE or contractor requirements are in jeopardy of being violated, particularly by the cumulative effect of multiple release points, facility operations may be restricted. If required by FDH, the Facility Manager may direct 324/327 and other facilities to limit the concentrations of radioactive materials released to the environment in airborne emissions during a specified period of time. All radionuclide releases are to be ALARA.

A warning trend is any significant radioactive emission trend increases (e.g. a rise of over 2 orders of magnitude) that are not consistent with the current plant condition. Routine analysis of record samples and daily review of stack CAM chart records for abnormal trends give indication of a warning trend or a reportable release.

Recovery Action: If a Plant Emergency Limit is exceeded:

- Suspend operations in areas ventilated by stack

AND

- Decrease stack flow by shutting down exhaust fans, as appropriate

AND

- Notify 324/327 Facility Manager, ECO and effluent cognizant engineer (see 1.2)

AND

- Provide additional notifications (i.e. to FDH, DOE, and WDOH) within 24 hours and submit documentation of the event (see 1.2)

AND

- Determine the cause and impact of the release

AND

- Prepare a written recovery plan with concurrence from the 324/327 Facility Manager, cognizant engineer and the ECO

If an annual limit is exceeded for a calendar year:

- Prepare a written response plan with concurrence from the 324/327 Facility Manager and the ECO.

- The ECO must notify WDOH within 24 hours of discovery. 
If a warning trend is indicated:

- Notify 324/327 Facility Manager, ECO and effluent cognizant engineer(see 1.2)

AND

- Determine the cause and impact of the release.

Basis for Limit: The emergency limits ensure prompt action is taken to preclude exposure of the public and/or the work force to airborne effluent radionuclides exceeding the levels determined to be safe for continuous exposure. These limits are specified in units indicated by the stack monitors. The Emergency Limit for the 324 facility is the emission quantity that would cause an offsite effective dose equivalent of $2 \mathrm{mrem} / \mathrm{event}$, as described in DOE/EH-0173T, as calculated in the FEMP. The 327 SAR establishes the Emergency Limit for the 327 facility as the emission quantity that would cause an offsite effective dose equivalent of $2 \mathrm{mrem} / \mathrm{event}$, as described in DOE/EH-0173T, in a 4-hour period, as calculated in the FEMP. These limits assume ${ }^{238} \mathrm{Pu}$ as the most restrictive alpha emitter present and ${ }^{90} \mathrm{Sr}(324)$ and ${ }^{137} \mathrm{Cs}(327)$ as the most restrictive beta emitters present.

Continuous sampling and monitoring of the higher risk effluents from radioactive control zones as required by Section 3.2 is necessary to ensure early detection of breakthrough of radioactivity, as well as to provide an auditable, continuing record of discharges. A continuous record is required by 40 CFR 61 , Subpart $H$. Therefore, continuous operation of samplers and the monitors for stacks EP-324-01-S and EP-327-01-S is required with timely repair and, in some cases, backup monitors or samplers available in the event of malfunction of the primary equipment. Periodic operation of sampler for stack EP-327-02-V is required to confirm continued low emissions. Daily operability inspections of the primary systems are performed during equipment operation. Functional tests of the systems and instrument calibrations provide reasonable assurance that the systems are operating properly. Accumulations of the sample analytical results and flow measurement data supports annual reporting to the DOE and regulatory agencies, as required by 40 CFR 61, Subpart H and WAC 246-247-080. 


\subsection{STACK EMISSION MEASUREMENT/MONITORING EQUIPMENT OPERABILITY}

\section{$\underline{\text { Variable }}$}

Sampler Operability

Sample Flow Rate

Instrument calibration

Radiation monitor test

Monitor downtime

Stack Flow Measurement

\section{Specification}

Primary or acceptable alternate instruments listed in Table 3.2 for sampling particulate radionuclide emissions of stacks EP-324-01-S and EP-327-01-S shall operate continuously when the associated stack fans are in service. The EP-327-02-V stack sampling system must operate periodically to confirm low emissions.

Isokinetic to maintain representative sampling, as described in the FEMP.

Instruments in Table 3.2 shall be calibrated annually.

Primary radiation monitoring systems listed in Table 3.2 shall be functionally tested on a monthly basis.

Stacks EP-324-01-S and EP-327-01-S monitoring system downtime for scheduled maintenance shall be limited to $4 \mathrm{~h} /$ day unless prior approval is obtained from the ECO.

Annual Vent \& Balance flow test, and following any long-term alterations to the exhaust system that could be expected to cause the average exhaust rate to differ by $+/-10 \%$ from the previously measured rate.

Detection/Control: Compliance with this limit is demonstrated by surveillance data sheets and preventive maintenance program records. For instruments listed in Table 3.2 and stack flow tests, exceeding the annual calibration or test frequency is a specification violation. See 1.2 and 1.3.1.

Recovery Action: If a primary instrument fails or malfunctions (stack EP-324-01-S or EP-327-01-S):

- Place an alternate system in service as quickly and efficiently as practicable after a failure is discovered

\section{AND}

- If a radiation monitor fails, place an alternate system in service within four hours or perform filter surveys at four-hour interval until replaced or corrected

AND

- Notify the 324/327 Facility Manager, ECO and effluent cognizant engineer (See Section 1.2) 
- Provide additional notifications (i.e. to FDH, DOE, and WDOH) within 24 hours if condition results in loss of emission measurement capabilities and persists for over 4 hours, and submit documentation of the event as required (see 1.2).

\section{AND}

- Initiate repair/replacement of the primary system within 96 hours.

If both the primary and alternate EP-324-01-S or EP-327-01-S instruments fail or malfunction:

- Discontinue operations with the potential to contribute airborne radionuclide emissions to the maximum extent compatible with safe operations within eight hours

AND

- Notify the 324/327 Facility Manager, ECO and effluent cognizant engineer (See Section 1.2)

AND

- Prepare a recovery plan with concurrence from the 324/327 Facility Manager and the ECO, which must be in effect within 72 hours.

If a stack flow measurement or Table 3.2 instrument calibration is not completed by the annual due date (i.e. by the end of the month in which it comes due), then:

- Notify the 324/327 Facility Manager, ECO and effluent cognizant engineer (See Section 1.2)

\section{AND}

- Provide additional notifications (i.e. to FDH, DOE, and WDOH) within 24 hours of discovery, and submit documentation of the event as required (see 1.2)

\section{AND}

- Complete instrument calibration or stack flow measurement as soon as possible.

Basis for Limit: Continuous sampling and monitoring of the higher risk effluents from radioactive control zones is necessary to ensure early detection of breakthrough of radioactivity and to provide an auditable, continuing record of discharges. A continuous record is required by 40 CFR 61, Subpart $H$. Therefore, continuous operation of samplers and the monitors for stacks EP-32401-S and EP-327-01-S is required with timely repair and, in some cases, backup monitors or samplers available in the event of malfunction of the primary equipment. Periodic operation* of stack EP-327-02-V sampler is required to confirm continued low emissions. The 4-hour monitor downtime limitation is based on DOE/EH-0173T as described in the 324/327 FEMP documents. For 327, the 4-hour monitor downtime limitation is also an OSR limit.

Daily operability inspections of the primary sampling and monitoring systems are performed during equipment operation, as required by HNF-PRO-450, HNF-PRO-2364, and by the 327 
OSR 2.4. Monthly functional tests of the systems and annual instrument calibrations provide reasonable assurance that the systems are operating properly, as required by HNF-PRO-450, HNF-PRO-2364, and by the 327 OSR 2.4. Accumulation of the sample analytical results and flow measurement data permit filing of annual reports to the DOE and regulatory agencies, as required by WAC 246-247 and 40 CFR 61, Subpart $H$.

* Approval for redesignation of this stack was obtained from WDOH and EPA, which allows for periodic sampling. WDOH approved sampling for a period of 4-weeks, once annually, during a representative period of stack operation. 
TABLE 3.2 STACK EFFLUENT MEASUREMENT/MONITORING INSTRUMENTATION

\begin{tabular}{|c|c|c|c|}
\hline STACK & SYSTEM & PRIMARY & ALTERNATE \\
\hline \multirow[t]{3}{*}{ EP-324-01-S } & $\begin{array}{l}\text { Particulate Radionuclide } \\
\text { Sample Flow }\end{array}$ & $\begin{array}{l}\text { 324D-SM-FI-001 \& } \\
\text { 324D-SM-PI-001 }\end{array}$ & \\
\hline & Alpha Particulate Monitor & $\begin{array}{l}\text { 324D-SMAB-RIS-001 } \\
\text { AND } \\
\text { 324-SM-UA-001 OR } \\
\text { 324-SM-UA-003 }\end{array}$ & $\begin{array}{l}\text { 324A-SMA-RIS-001 } \\
\text { AND } \\
\text { 324-SM-UA-001 OR } \\
\text { 324-SM-UA-003 OR } \\
\text { Surveillance of CAM } \\
\text { chart recorder, or CAM } \\
\text { or sample filter survey at } \\
\text { <4-hour intervals. }\end{array}$ \\
\hline & $\begin{array}{l}\text { Beta/Gamma Particulate } \\
\text { Monitor }\end{array}$ & $\begin{array}{l}\text { 324D-SMAB-RIS-001 } \\
\text { AND } \\
\text { 324-SM-UA-001 OR } \\
\text { 324-SM-UA-003 }\end{array}$ & $\begin{array}{l}\text { 324A-SMB-RIS-001 } \\
\text { AND } \\
\text { 324-SM-UA-001 OR } \\
\text { 324-SM-UA-003 OR } \\
\text { Surveillance of CAM } \\
\text { chart recorder, or CAM } \\
\text { or sample filter survey at } \\
\leq 4-\text {-hour intervals. }\end{array}$ \\
\hline \multirow[t]{3}{*}{ EP-327-01-S } & $\begin{array}{l}\text { Particulate Radionuclide } \\
\text { Sample Flow }\end{array}$ & $\begin{array}{l}\text { 327-SM1-FI-001 AND } \\
327-S M 1-P I-001\end{array}$ & \\
\hline & Alpha Particulate Monitor & $\begin{array}{l}\text { 327-SMA-RIS-001 AND } \\
\text { 327-SM-RA-001 OR } \\
\text { 327-SM-RA-002 }\end{array}$ & \\
\hline & $\begin{array}{l}\text { Beta/Gamma Particulate } \\
\text { Monitor }\end{array}$ & $\begin{array}{l}\text { 327-SMB-RIS-001 AND } \\
\text { 327-SM-RA-001 OR } \\
\text { 327-SM-RA-002 }\end{array}$ & $\begin{array}{l}\text { Surveillance of CAM } \\
\text { chart recorder, or CAM } \\
\text { or sample filter survey at } \\
\leq 4 \text {-hour intervals. }\end{array}$ \\
\hline EP-327-02-V & $\begin{array}{l}\text { Particulate Radionuclide } \\
\text { Sample Flow* }\end{array}$ & $\begin{array}{l}\text { 327-SM2-FI-001 \& } \\
\text { 327-SM2-PI-001 }\end{array}$ & \\
\hline
\end{tabular}

* Required periodically, during sampling periods only.

NOTE: Where a primary instrument is listed, all instruments that are necessary for the function of the listed instrument are included. For example, where a monitor alarm is listed, the radiation detector, vacuum pump, and sample collector must be operable. 


\subsection{STACK SAMPLE VACUUM PUMPS}

\section{Variable}

Pump Operability

Pump Switching Capability
Specification

324-SM-P-001 or 002 operating

Primary 327-VAS-BLW-B001 or B002 operating or local backup stack vacuum pumps operating.

Pressure switch 324D-SM-PS-001 operable, 327 FMCS VAS failure alarm operable.

Detection/Control: Pump operation is verified by the instruments listed below. Calibration of these instruments is conducted annually.

TABLE 3.3 INSTRUMENTS

\begin{tabular}{|l|l|l|}
\hline \multicolumn{1}{|c|}{ EQUIPMENT } & \multicolumn{1}{|c|}{ PRIMARY } & ALTERNATE \\
\hline $\begin{array}{l}\text { 324D-SM-P-001 or } \\
\text { 324D-SM-P-002 }\end{array}$ & SM-PS-001 & SM-PAS-001 \\
\hline $\begin{array}{l}\text { 327-VAS-BLW-B001 } \\
\text { or 327-VAS-BLW- } \\
\text { B002 }\end{array}$ & $\begin{array}{l}\text { FMCS VAS } \\
\text { Failure Alarm }\end{array}$ & $\begin{array}{l}\text { VAS-PI-B001 } \\
\text { or VAS-PI- } \\
\text { B002 }\end{array}$ \\
\hline
\end{tabular}

Recovery Action: If one primary vacuum pump fails:

- Ensure other primary vacuum pump is operating within 4 hours of failure

AND

- Notify 324/327 Facility manager, ECO and effluent cognizant engineer

AND

- Initiate repair within 96 hours.

If both primary vacuum pumps fail:

- Notify 324/327 Facility Manager, ECO and effluent cognizant engineer (see section 1.2)

AND

- Place an alternate vacuum pump in service within 4 hours

OR

- Discontinue operations with the potential to contribute airborne radionuclide emissions to the 
maximum extent compatible with safe operations within eight hours

\begin{abstract}
AND
- Provide additional notifications (i.e. to FDH, DOE, and WDOH) within 24 hours if condition persists for over 4 hours and submit documentation of the event as required (see 1.2).
\end{abstract}

\begin{abstract}
AND
- Prepare a recovery plan, which also addresses airborne effluent sampling/monitoring and actions necessary to perform routine data collection/observation, approved by the $324 / 327$ Facility Manager, ECO and effluent cognizant engineer.

Basis for Limit: A dedicated vacuum system is provided to service the 324 building main stack and effluent system samplers and monitors. Loss of this vacuum system would result in loss of airborne effluent samplers and monitors, requiring alternate effluent sampling methods. A central vacuum system is provided to service the 327 building room air samplers and monitors and effluent system samplers and monitors. Loss of the 327 centralized vacuum system would result in a loss of building and airborne effluent samplers and monitors, requiring operation of backup vacuum pumps.
\end{abstract}

EPA 40 CFR 61, Subpart H (NESHAP) requires continuous sampling of 324/327 main stack emissions for reporting purposes. Continuous monitoring of 324/327 main stack emissions is required by FDH through HNF-PRO-450 and by the 324/327 facility SARs (HNF-SD-SPJ-SAR001, Rev 1, and HNF-SD-SPJ-SAR-002, Rev1). 


\subsection{LIQUID EFFLUENT SPECIFICATIONS}

\subsection{RPS/PS pH / $\mathrm{pH}$ MONITOR}

$\underline{\text { Variable }}$

Non-dangerous waste $\mathrm{pH}$ criteria

TEDF waste acceptance $\mathrm{pH}$ criteria

pH Alarm set points

$\mathrm{pH}$ Monitors operability

pH Monitor calibration
Specification

Between 2.0 and 12.5

Between 6 and 11

N/A

N/A

N/A

Detection/Control: Batches should be tested to determine $\mathrm{pH}$ if $\mathrm{pH}$ is suspect, according to process knowledge. Batches outside the TEDF $\mathrm{pH}$ criteria require 300 Area LEF approval prior to disposal.

Basis for Limit: The $\mathrm{pH}$ requirements for the RPS/PS are intended to prevent discharge of a dangerous waste and to support compliance with TEDF waste acceptance criteria. The 324/327 Facilities comply with WMH-320, 300 Area Liquid Effluent Facilities Administration, section 3.4, Liquid Waste Certification Program requirement to "Ensure discharges continue to meet the Waste Acceptance Criteria" by various administrative and engineering controls. These controls include training, procedures, inventory, drain-design and posting. Conductivity and $\mathrm{pH}$ monitors have been determined to be unnecessary for 324/327 because sufficient administrative and engineering controls prevent out-of-spec releases. Hazardous material inventories are minimized. In addition, most PS and RPS floor drains and access points have been isolated, labeled or elevated prevent inadvertent chemical releases from spills. In addition to all this, the facilities have effective waste training and waste management programs to disposition all dangerous wastes without using PS/RPS drains. 


\subsection{RPS/PS RADIONUCLIDE CONCENTRATIONS/ RPS RADIATION MONITORS/DIVERTERS}

Variable

Annual-Average Radionuclide

Concentration

Batch Radionuclide Concentration

RPS Radiation Monitor/Diverter Operability

Monitor Calibration
Specification

See Table below.

Determine concentration of radioactive contamination for each potentially contaminated effluent batch that is discharged to 300 Area TEDF.

Required when there is RPS flow to the 307 basins (see Recovery Action).

Annually.

ANNUAL RPS/PS CONCENTRATION LIMITS
\begin{tabular}{|l|l|}
\hline Isotope & LIMIT $(\mathrm{pCi} / \mathrm{L})$ \\
\hline Total Beta & 50 \\
\hline Total Alpha & 15 \\
\hline
\end{tabular}

Detection/Control: Radiation alarms indicate detection of upset, and automatic diversion to the RLWS* is the control. RPS diversions are indicated at the main facility alarm panels. Monthly functional tests ensure proper operation of the 324 Room 18 REC RPS radiation monitor. 300 Area LEF is responsible for surveillance, functional tests and calibration of the other monitors/diverters.

Compliance with the concentration limits is demonstrated by laboratory analyses of samples from batch transfers to the RPS with suspected potential radioactive contamination. If a batch exceeds the concentration limit, approval must be obtained from 300 Area LEF prior to disposal.

INSTRUMENTS

\begin{tabular}{|c|c|}
\hline EQUIPMENT & PRIMARY \\
\hline $\begin{array}{c}\text { 324 RPS MONITOR - } \\
\text { Service Tunnel }\end{array}$ & $\begin{array}{c}\text { Diversion Station Alarm, Service } \\
\text { Tunnel }\end{array}$ \\
\hline $\begin{array}{c}\text { 324 REC RPS MONITOR - } \\
\text { Room 18 }\end{array}$ & $\begin{array}{c}\text { Diversion System Room 18 } \\
\text { Divert Alarm }\end{array}$ \\
\hline $\begin{array}{c}\text { 327 RPS MONITOR - } \\
\text { Basement }\end{array}$ & Diversion Station Alarm \\
\hline
\end{tabular}

At the time of revision 1 of this document, the RPS diversion capability is dead-headed, i.e. it is isolated from the 340 Facility RLWS and internal facility RLWS. The diverters continue to 
perform the function of preventing out-of-spec effluent from discharging to the 307 basins. Plans are in progress to reconnect the RPS diversion capabilities to alternate storage within the facilities.

\section{Recovery Action:}

If a radiation monitor/diverter alarm is activated:

- Isolate all RPS sources immediately to prevent potential flooding

AND

- Obtain a sample of the effluent, if possible,

AND

- Notify 324/327 Facility Manager, ECO, effluent cognizant engineer and 300 Area LEF (see 1.2)

AND

- Conduct an investigation to determine cause.

If Room 18 RPS radiation monitor fails:

- Cease activities that could result in out-of-specification effluent

OR

- Maintain proportional sampler and analyze for beta-gamma and alpha every week

AND

- Notify 300 Area Liquid Effluent Facility (LEF) of the malfunction

AND

- Initiate repair or replacement of monitor within 96 hours.

If the 324 service tunnel or 327 basement RPS radiation monitor fails:

- Cease activities that could result in out-of-specification effluent, as required, coordinating responses with 300 Area LEF. 
If an annual limit is exceeded for a calendar year:

- Prepare a recovery plan with concurrence from the 324/327 Facility Manager, ECO, effluent cognizant engineer, and 300 Area LEF.

Basis for Limit: The 324 Facility is responsible for maintenance of the monitor located in room 18. The Room 18 monitor requirements will no longer apply once this stream is rerouted to the service tunnel monitor (bypassing the Room 18 monitor). The 300 Area LEF is responsible for maintenance of the RPS monitors located in the 324-service tunnel and the 327 basement.

The 300 Area Liquid Effluent Facilities Administration, Liquid Waste Certification Program (WMH-320, section 3.4), states that waste-generating facilities "Ensure discharges continue to meet the Waste Acceptance Criteria". The discharge limits for radionuclide concentrations in liquid effluent streams are specified in the Waste Acceptance Criteria for the 300 Area Process Sewer and \& TEDF, section 3.3 of WMH-320. These limits are driven by the EPA NPDES Permit WA-002591-7, which regulates the 300 Area TEDF discharges. The RPS stream is intended to service potentially contaminated liquid effluents. The PS stream is intended to service non-potentially contaminated liquid effluents. In all cases ALARA will be practiced. 


\subsection{RPS/PS FLOW MEASUREMENT}

\section{Variable}

Batch Volume Measurement

Flow measurement

Maximum flow rates

Flow measurement device calibration

\section{$\underline{\text { Specification }}$}

Determine quantity of each potentially contaminated effluent batch that is discharged to 300 Area TEDF.

Continuous during flow to the 300 Area TEDF.

See table below.

Frequency as required through PM system, for equipment identified below.

Detection/Control:

RPS/PS FLOW MEASUREMENT

\begin{tabular}{|l|l||l||}
\hline PRIMARY & ALTERNATE & MAXIMUM FLOW (gpm) \\
\hline 324 PS Flow meter & Periodic visual inspections & 60 \\
\hline 324 RPS Flow meter & Periodic visual inspections & 11 \\
\hline 327 RPS Flow meter & Periodic visual inspections & 50 \\
\hline
\end{tabular}

Recovery Action: If the flow recorder fails:

- Initiate repair or replacement of monitor

\section{AND}

- Estimate the flow based on plant conditions as required by 300 Area LEF.

Basis for Limit: In letter "Design Flowrates for Replacement 300 Area Process Sewer System", Project L-070, T.B. Veneziano to T.D. Chikalla, dated September 23, 1994, agreement was made to maintain 324/327 effluents within the maximum flow rates specified in the Facility Liquid Waste Certification Plan. The approved 324 facility 300 Area Liquid Effluent Facilities Administration, Liquid Waste Certification Program, section 3.4 of WMH-320, states that waste generating facilities "Ensures all personnel who control discharge materials to either the PS or RPS systems are aware of the system limitations". The equipment operability requirements provide assurance that the flow measurement systems are in constant service during operation or alternate measures are taken to obtain the required information. The calibration requirements help to ensure the systems are functioning properly. 


\subsection{RPS/PS CHEMICAL CONCENTRATIONS}

Variable

RPS/PS chemical concentrations

Special sample analyses

Conductivity monitor operability

Conductivity monitor calibration

\section{Specification}

Below and dangerous waste limits. TEDF Waste Acceptance Criteria are provided in WMH-320, and dangerous waste limits are provided in WAC 173-303.

Required when there is any reason to believe that a hazardous substance is entering an effluent stream at levels which approach the specification limits.

N/A

N/A

Detection/Control: Analysis of special samples.

Basis for Limit: The TEDF Waste Acceptance Criteria are provided in section 3.3 of WMH-320. The limits for dangerous wastes and other substances are provided in WAC 173-303. The 324/327 Facilities comply with WMH-320, 300 Area Liquid Effluent Facilities Administration, section 3.4, Liquid Waste Certification Program requirement to "Ensure discharges continue to meet the Waste Acceptance Criteria" by various administrative and engineering controls. These controls include training, procedures, inventory, drain-design and posting. Conductivity and $\mathrm{pH}$ monitors have been determined to be unnecessary for 324/327 because sufficient administrative and engineering controls prevent out-of-spec releases.

Hazardous material inventories are minimized. In addition, most PS and RPS floor drains and access points have been isolated, labeled or elevated prevent inadvertent chemical releases from spills. In addition to all this, the facilities have effective waste training and waste management programs to disposition all dangerous wastes without using PS/RPS drains. 


\title{
4.5 327 RPS SUMP
}

$\underline{\text { Variable }}$

RPS pump operability

Sump level indication/control operability

\section{Specification}

Operable

Detection/Control: Routine observation/recording of level indication; pump functional checks.

Recovery Action: If one pump fails:

- Initiate repair of pump within $96 \mathrm{~h}$

If second pump fails:

- Report condition to 327 Facility Manager, ECO and effluent cognizant engineer

AND

- Shut off sources to the sump

Calibrate annually.

AND

- Shut off sources to the sump

AND

- Initiate repair of pump within 96 hours.

If the level indicator fails:

- Initiate repair or replacement within 96 hours.

\begin{abstract}
AND
Notify the 327 Facility Manager, ECO and effluent cognizant engineer

Basis for Limit: A small volume stream continues to be discharged to the 327 RPS sump. The sump is automatically pumped out to the 307 retention basins based on level controls. The sump level control calibration program helps ensure that the level control system will function properly and/or that alarms will sound to ensure that a pump will be turned on manually if the level exceeds the control value. The actions to shut off sources and initiate repair within 96-hours if pump fails is a recommendation to minimize overflow.
\end{abstract}




\subsection{RPS/PS COMPOSITE SAMPLERS}

\section{Variable}

Sampler operability

\section{Specification}

Not currently required by the 300 Area Treated Effluent Disposal Facility (TEDF). May remain out-of-service unless required by TEDF.

Detection/Control: $\quad$ N/A

Recovery Action: $\quad$ N/A

Basis for Limit: Sampling stations are located on the PS and RPS streams. The sampling stations include proportional samplers and sample flow-measurement totalizing instrument. Past samples were taken in preparation of the Liquid Waste Certification Plan, but are not currently required.

\subsection{DISCHARGES TO THE GROUND}

Variable

Discharge to the soil

\section{Specification}

Discharge to the ground must be in accordance with Department of Ecology permits.

Detection/Control: Routine surveillance.

Recovery Action: If an unplanned discharge is discovered:

- Notify 324/327 Facility Manager, ECO and effluent cognizant engineer (see 1.2)

AND

- Determine cause.

Basis for Limit: Tri-party agreements have restricted the use of cribs for disposal of waste, and Washington State Department of Ecology permits ST 4508 and ST 4509 regulate other discharges to the ground. Requirements are provided in HNF-PRO-455. If discharge could potentially result in radioactive air emissions, notification is required to FDH, DOE and WDOH in accordance with HNF-PRO-453, ENVIRONMENTAL NOTIFICATION AND REPORTING. 


\subsection{DISCHARGES TO THE RLWS SYSTEM / RLWS SUMP}

Variable

Discharge/Transfer to RLWS

\section{Specification}

Discharges/transfers are no longer allowed to the 340 facility. Lines connecting 324/327 RLWS to the 340 facility have been isolated.

Detection/Control: Discharge to the to the 327 RLWS pipe system is indicated by activation of the low-point alarm, which is triggered by a liquid detector is located in the 327 RLWS main line. Discharge to the 327 RLWS sump is indicated by the RLWS high alarm, which is triggered by a float located in the sump. Both alarm at the 327 main alarm panel.

Discharge into the 324 RLWS pipe system is detected and indicated by the High Liquid Level Room \#4 RLWS Sump alarm and the Room 3F RLWS sump alarm which are on the main alarm panel (room 3F and tank-177 are currently isolated from the facility RLWS system).

\section{Recovery Action:}

If an RLWS Low Point Alarm activates,

- Notify 324/327 Facility Manager, ECO, effluent cognizant engineer and 300 Area LEF (see 1.2)

- Determine cause

AND

\section{AND}

- Perform and document an inspection of the visible accessible portions of the RLWS piping system and ancillary equipment within 24 hours of discovery of the discharge for potential leaks or releases. The visual inspection at 324 will consist of the RLWS piping from tank Tk177 through the service tunnel, as appropriate. The visual inspection at 327 will consist of the visible accessible shielded RLWS piping, some at a distance due to high radiation concerns.

Basis for Limit: The 340 facility no longer provides RLWS service to the 327 \& 327 facilities. On October 1, 1998, the RLWS lines between the $324 / 327$ facilities and the 340 facility were isolated at the valve boxes to prevent any discharge to the 340 facility. In 1999, these routes to the 340 facility were permanently blanked. The facility diverters will remain active in order to prevent diverted water from discharging to the 307 basins, but will divert to the RLWS piping system within the facility. The $324 / 327$ facilities currently have no contingency for diversions that could lead to flooding in the buildings other than isolating sources. The regulatory requirements for containment and detection of releases for the RLWS is from WAC 173-303-200(b), which calls for compliance with WAC 173-303-640(2) through (10) for any liquids containing dangerous waste. 


\section{APPENDIX - SPECIFICATION TRACEABILITY MATRIX}

\begin{tabular}{|c|c|c|c|}
\hline \multicolumn{4}{|c|}{ SPECIFICATION TRACEABILITY MATRIX } \\
\hline SPECIFICATION & $\begin{array}{l}\text { REQUIREMENT SOURCE } \\
\text { DOCUMENT }\end{array}$ & $\begin{array}{l}\text { OPERATING / } \\
\text { MAINTENANCE } \\
\text { PROCEDURE }\end{array}$ & RECORD \\
\hline $\begin{array}{l}1.2 \text { REPORTING } \\
\text { REQUIREMENTS }\end{array}$ & HNF-PRO-450 & - & $\begin{array}{l}\text { Notifications, } \\
\text { Occurrence } \\
\text { Reports }\end{array}$ \\
\hline $\begin{array}{ll}1.5 & \text { RECORD } \\
\text { RETENTION } & \\
\text { REQUIREMENTS }\end{array}$ & $\begin{array}{l}\text { HNF-AOP-97-1 (draft) } \\
\text { HNF-PRO-450 } \\
\text { (BWHC scanning waiver) }\end{array}$ & ---- & 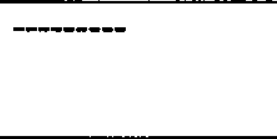 \\
\hline $2.1 \quad$ EXHAUST FANS & HNF-AOP-97-1 (draft) & $\begin{array}{l}\text { 3I-SOP-PWR-002 } \\
\text { 3M-SOP-PWR-005 } \\
\text { 3I-PWR-ALM-001 } \\
\text { 3M-PWR-ALM-001 } \\
\end{array}$ & $\begin{array}{l}\text { Surveillance } \\
\text { Checklist }\end{array}$ \\
\hline $\begin{array}{l}2.2 \text { ZONES I \& II } \\
\text { DIFFERENTIAL } \\
\text { PRESSURES }\end{array}$ & WAC 246-247-075(8) & $\begin{array}{l}\text { 3I-SOP-PWR-002 } \\
\text { 3M-SOP-PWR-005 } \\
\text { 3I-PWR-ALM-001 } \\
\text { 3M-PWR-ALM-001 } \\
\end{array}$ & "N/A \\
\hline $\begin{array}{l}2.3 \quad \text { NEW HEPA } \\
\text { FILTERS }\end{array}$ & $\begin{array}{l}\text { WAC 246-247 (ANSI/ASME } \\
\text { N510) }\end{array}$ & N/A & *N/A \\
\hline $\begin{array}{l}2.4 \quad \text { INSTALLED } \\
\text { FILTER EFFICIENCY }\end{array}$ & $\begin{array}{l}\text { WAC 246-247 (ERDA 76-21) } \\
\text { HNF-PRO-450 } \\
\text { HNF-SD-SPJ-OSR-001, Rev1 } \\
\text { HNF-SD-SPJ-OSR-002, Rev2 }\end{array}$ & 3105008 (DOS Test) & Data Sheets \\
\hline $\begin{array}{l}2.5 \quad \text { INSTALLED } \\
\text { FILTER DIFFERENTIAL } \\
\text { PRESSURE (DP) }\end{array}$ & $\begin{array}{l}\text { HNF-PRO-450 } \\
\text { NOC AIR 95-903 (B-Cell) } \\
\text { WDOH (Annual cal precedent) }\end{array}$ & $\begin{array}{l}\text { 3-IC-003 (DPI) } \\
\text { 3-IC-008 (DPI) } \\
\text { 3MVB001 (DP Test) } \\
\text { 3I-SOP-PWR-002 } \\
\text { 3M-SOP-PWR-005 } \\
\end{array}$ & $\begin{array}{l}\text { Calibration or } \\
\text { Test Data } \\
\text { Sheets, } \\
\text { Surveillance } \\
\text { Checklist } \\
\end{array}$ \\
\hline $\begin{array}{l}3.1 \quad \text { STACK } \\
\text { RADIONUCLIDE } \\
\text { EMISSION LIMITS }\end{array}$ & $\begin{array}{l}40 \text { CFR } 61.92-94 \text { (limit, } \\
\text { measurement, reporting) } \\
\text { DOE/EH-0173T } \\
\text { WAC 246-247-080 (reporting) } \\
\text { HNF-SD-SPJ-OSR-002, Rev2 }\end{array}$ & $\begin{array}{l}\text { 3IM-SOP-ENV-001 } \\
\text { 3IM-SOP-ENV-004 } \\
\text { 3I-PWR-ALM-001 } \\
\text { 3M-PWR-ALM-001 }\end{array}$ & $\begin{array}{l}\text { ERS Database, } \\
\text { Annual Emission } \\
\text { Reports }\end{array}$ \\
\hline
\end{tabular}




\begin{tabular}{|c|c|c|c|}
\hline $\begin{array}{l}3.2 \text { STACK EMISSION } \\
\text { MEASUREMENT / } \\
\text { MONITORING } \\
\text { EQUIPMENT } \\
\text { OPERABILITY }\end{array}$ & $\begin{array}{l}40 \text { CFR } 61.93 \text { (ANSI N13.1) } \\
\text { WAC 246-247-075 } \\
\text { DOE/EH-0173T } \\
\text { WDOH (Annual cal precedent) } \\
\text { NOC AIR 95-903 (B-Cell) } \\
\text { HNF-AOP-97-1 (draft) } \\
\text { HNF-PRO-450 } \\
\text { HNF-PRO-2364 } \\
\text { HNF-SD-SPJ-OSR-002, Rev2 } \\
\text { HNF-SD-SPJ-SAR-001, Rev1 } \\
\text { HNF-SD-SPJ-SAR-002, Rev1 }\end{array}$ & $\begin{array}{l}\text { 3IM-SOP-ENV-001 } \\
\text { 3IM-SOP-ENV-004 } \\
\text { 3IM-SOP-ENV-005 } \\
\text { 3I-SOP-ENV-006 } \\
\text { 3I-PWR-ALM-001 } \\
\text { 3M-PWR-ALM-001 } \\
\text { 3-IC-003 (PI) } \\
\text { 3-IC-029 (324D } \\
\text { alpha/beta monitor) } \\
\text { 3I05005 (V\&B Stack } \\
\text { Flow) } \\
\text { 3MVB018 (V\&B } \\
\text { Stack Flow) }\end{array}$ & $\begin{array}{l}\text { Calibration Data } \\
\text { Sheets, } \\
\text { Daily } \\
\text { Surveillance } \\
\text { Checklists, } \\
\text { Monthly Source- } \\
\text { Check Data, } \\
\text { Annual Stack } \\
\text { Flow Data, } \\
\text { COCs }\end{array}$ \\
\hline $\begin{array}{l}3.3 \text { STACK SAMPLE } \\
\text { VACUUM PUMPS }\end{array}$ & $\begin{array}{l}40 \text { CFR } 61.93 \text { (ANSI N13.1) } \\
\text { WAC 246-247 } \\
\text { DOE/EH-0173T } \\
\text { HNF-PRO-450 } \\
\text { HNF-PRO-2364 } \\
\text { HNF-SD-SPJ-OSR-002, Rev2 }\end{array}$ & $\begin{array}{l}\text { 3-IC-008 (PI/PAS) } \\
\text { 3-IC-025 (PS) } \\
\text { 3I23015 (Vacuum } \\
\text { Blowers) } \\
\text { 3I-SOP-PWR-002 } \\
\text { 3M-SOP-PWR-006 } \\
\text { 3I-PWR-ALM-001 }\end{array}$ & ${ }^{*} \mathrm{~N} / \mathrm{A}$ \\
\hline $\begin{array}{l}4.1 \quad \text { RPS/PS pH } / \mathrm{pH} \\
\text { MONITOR }\end{array}$ & WMH-320 & $* \mathrm{~N} / \mathrm{A}$ & $* \mathrm{~N} / \mathrm{A}$ \\
\hline $\begin{array}{l}4.2 \quad \text { RPS/PS } \\
\text { RADIONUCLIDE } \\
\text { CONCENTRATIONS / } \\
\text { RPS RADIATION } \\
\text { MONITORS/DIVERTERS }\end{array}$ & WMH-320 & $\begin{array}{l}\text { 3I18010 (Rm 18) } \\
\text { 3I-PWR-ALM-001 } \\
\text { 3M-PWR-ALM-001 }\end{array}$ & ${ }^{*} \mathrm{~N} / \mathrm{A}$ \\
\hline $\begin{array}{l}4.3 \quad \text { RPS/PS FLOW } \\
\text { MEASUREMENT }\end{array}$ & WMH-320 & $\begin{array}{l}\text { Cal } 50 \\
\text { Cal } 51 \\
\text { 3I-SOP-PWR-002 } \\
\end{array}$ & ${ }^{*} \mathrm{~N} / \mathrm{A}$ \\
\hline $\begin{array}{l}4.4 \quad \text { RPS/PS } \\
\text { CHEMICAL } \\
\text { CONCENTRATIONS }\end{array}$ & $\begin{array}{l}\text { WAC 173-303 } \\
\text { WMH-320 }\end{array}$ & $*$ N/A & ${ }^{*} \mathrm{~N} / \mathrm{A}$ \\
\hline $4.5 \quad 327$ RPS SUMP & BMP & $\begin{array}{l}\text { 3M18001 } \\
\text { 3M-PWR-ALM-001 }\end{array}$ & ${ }^{*} \mathrm{~N} / \mathrm{A}$ \\
\hline $\begin{array}{ll}4.6 & \mathrm{RPS} / \mathrm{PS} \\
\text { COMPOSITE SAMPLERS }\end{array}$ & N/A & - & ${ }^{*} \mathrm{~N} / \mathrm{A}$ \\
\hline $\begin{array}{l}4.7 \quad \text { DISCHARGES TO } \\
\text { THE GROUND }\end{array}$ & $\begin{array}{l}\text { Ecology permits ST } 4508 \text { and } \\
\text { ST } 4509 \\
\text { HNF-PRO-455 }\end{array}$ & |------- & - \\
\hline $\begin{array}{l}4.8 \text { DISCHARGES TO } \\
\text { THE RLWS SYSTEM/ } \\
\text { RLWS SUMP }\end{array}$ & $\begin{array}{l}\text { WAC } 173-303-200(\mathrm{~b}) \\
\text { WAC } 173-303-640(2)-(10) \\
\text { Silver List }\end{array}$ & $\begin{array}{l}\text { 3I-PWR-ALM-001 } \\
\text { 3M-PWR-ALM-001 }\end{array}$ & ------ \\
\hline
\end{tabular}

* Since no direct control or monitoring regulatory data is obtained from this equipment, preventive maintenance or calibration records are not retained for regulatory purposes. 